AGRARIS: Journal of Agribusiness and Rural Development Research

Vol. 6 No. 2: July-December 2020

Article history:

Submitted: February $12^{\text {th }}, 2020$

Accepted: October $15^{\text {th }}, 2020$

\section{Marliati*}

Prodi Magister Manajemen Agribisnis, Universitas Islam Riau, Indonesia

*)Correspondence email: marliatiahmad@agr.uir.ac.id

\title{
Factors Influencing on Entrepreneurial Behavior of Street Vendors (A Case in Pekanbaru City, Riau Province)
}

DOI: https://doi.org/10.18196/agr.6296

\begin{abstract}
One of the informal sectors that happening in urban areas is street vendors, known for its contribution to reduce unemployment despite their existence are often raise urban planning problems. However, street vendors should be given the opportunities by the government to increase their economic empowerment and competitiveness. The purpose of this study is to analyze personal characteristics and business profile, family environment, internal and external environment of the business; and its influence on street vendors' entrepreneurial behavior. The research was conducted in Pekanbaru from March to December 2019. Respondents of the study are 131 street vendors. The data is analyzed by using the Partial Least Square (PLS) method. The results showed that the average personal characteristics of street vendors' aged 36.93 years, level of education equivalent to high school with 5.27 years of business experience and average net income per day is IDR 442,404 which 52.7 percent do not have any business license. The family environment and the internal business environment are considered "good" and support street vendors. The external business environment, especially government support or policies (capital support, technology and empowerment) are still considered "not good" by street vendors. Factors that have a significant influence on entrepreneurial behavior are: formal education factors, parent education method, family support, business financial analysis skills and government support or policies (access to business capital and empowerment).
\end{abstract}

Keywords: Entrepreneurial Behavior, Street Vendor, Street Food

\section{INTRODUCTION}

In a business perspective, according to the category of Bank Indonesia (2015) the informal sector such as street vendors are a group of Small and Medium Enterprises (SMEs). According to Hadya Jayani (2020), SMEs (including street vendors) have an important and strategic role in national economic development. Apart from having impact in economic growth and employment, SMEs also have important role in the distribution of development results. Based on data from Bank Indonesia, (2015), the number of entrepreneurs in Indonesia reached $56,539,560$ units and most of them $56,534,592$ units or $99.99 \%$ are SMEs. Based on BPS data (2020), SMEs have a contribution of $60.3 \%$ of Indonesia's total 
gross domestic product (GDP). In addition, SMEs absorb 97\% frome the total workforce and 99\% of total employment. In 2018, there were 64.2 million units of SMEs.

The business circumstance in Riau currently is still dominated by businesses classified as micro and small enterprises (SMEs), including the informal sectors such as street vendors. Based on the results of the 2016 Advanced Economic Census, the number of these businesses reached 509.000 or 98.26 percent of the total non-agricultural businesses in Riau province. This business is also able to absorb Riau's workforce of more than 1.24 million people or about 67.68 percent of the total workforce outside the agricultural sector in Riau. While Indonesia hit by crisis around 1997-1998, SMEs proved to be standing firm when other large businesses fell (BPS Riau Province, 2018).

Pekanbaru City that has the largest population in Riau is the center of SMEs including the street vendors. The number of SMEs in this city is around 19.47 percent of the total number of SMEs in Riau, which is being the largest in number compared to other regencies/cities. Second after that, around 13.50 percent of SMEs are located in Kampar Regency and the rest are spread across ten districts/cities in Riau (BPS Riau Province, 2018).

The strong point of the street vendors as part of SMEs in surviving the global crisis are for various reasons. First, this sector generally produces consumer goods and services that are most needed by consumers. Second, this business does not rely on imported raw materials and makes more use of local resources in terms of human resources, capital, raw materials, and equipment. Third, in general, this type of business uses owner's capital or not rely on bank's loan. With these advantages, SMEs and including the street vendors that are not significantly affected by global crisis which usually marked by a steep decline in the rupiah exchange rate (BPS Riau Province, 2018). This has proven the role of SMEs, including the informal sector, in the national and regional economy stability.

Even though has several advantages, street vendor as part of SMEs also has many limitations and does not always running well, they still facing many obstacles, both from internal and external that must be faced by SMEs, which make it difficult for this business to be able to develop. According to BPS Riau Province (2018), these limitations include the lack of banking access; the capability and knowledge of human resources is still low; traditional management; limited use of technology; and disability to adapt with consumer tastes especially with export-oriented preferences.

The similar opinion was conveyed by Bank Indonesia (2015), the main problems of SMEs in Indonesia are; internal and external business problems. Internal factors include: Capital, Human Resources, Law and accountability. External problems are: Business climate, infrastructure and access. In detail, the SMEs problems are: Around $60-70 \%$ have not received access or financing. The businesss management of SMEs is still operated traditionally and manually, for the most part is in financial management. The household money is still can not divided from business operations's money by the managers.

Thus, the rising of SMEs including the street vendor on the one hand can help the government specifically in reducing the number of unemployment, providing income for households and also increasing regional income. On the other hand it will also cause problems 
in urban area arrangement (Sulistyo Rini, 2013, Purnawati, 2016). The increasing number of street vendors in the city center produces unsightly landscape and generate problems such as urban cleanliness and neatness.

The main problems faced by micro entrepreneurs such as street vendors are instability in business and lack of funding access. This study focuses on the study of street food vendors. The identification of street vendor problems and performances is expected to have contribution and assisted government to develop SMEs both through guidance and preparation of regulations so as to protect and improve the performance of SMEs, it must also receive business opportunities and government attention so that economically competitive and empowered.

Several studies have shown that there is a significant influence between entrepreneurial behavior and business success. In addition, it can be concluded that entrepreneurial behavior is influenced by a number of internal and external business factors (Suharti \& Sirine, 2011; Azwar, 2013; Shirokova, et al. 2014; Desi Martauli et al., 2016; Buddhi Satyarini, 2016 dan Nursiah et al., 2017).

Based on various literature reviews (Schmidt et al., 2018), trying to synthesize the dimensions of entrepreneurial behavior between various terms and concepts into a set of basic ideas or dimensions of entrepreneurial behavior. The dimensions of entrepreneurial behavior are: creative, leadership, planner, seizing opportunities, persistence / resilience, courage to take risks, independence and socialization skills. The business environment is the dynamic of the business environment that affects business performance, which consists of the internal environment (micro) and the economic environment which is the external (macro) environment. Based on the background and theoretical studies, the research objectives were to analyze: personal characteristics and business profiles; the family environment, the internal and external environment of the business; entrepreneurial behavior; and factors that influence the entrepreneurial behavior of street vendors of food in Pekanbaru City.

\section{RESEARCH METHOD}

\section{Research Time and Location}

The research location is in Pekanbaru City, Riau Province. The location is selected based on the consideration that Pekanbaru City as the capital of Riau Province is the center of government, education, culture, urbanization and economic activities which of course had an impact on population growth, business opportunities and market opportunities for the street vendors, especially street food. The research was conducted for 12 months, from March 2019 to February 2020.

\section{Sampling Procedure and Data Collection}

Respondents were street food vendors in Pekanbaru City. Respondent is selected using purposive sampling technique. This is in accordance with the objectives of this study with the criteria of research respondents, such as: (1) street vendors who sell street food (self-processed agro-industry products) at prime locations, (2) places, along roadside with temporary carts or 
tents. Respondents were 131 street vendors selling food in nine center locations of street food in six sub-districts in Pekanbaru City.

The data collected consists of primary and secondary data. Primary data obtained through in-depth interviews (depth interview) and observations (observations) in the field. Primary data collected include: Characteristics of Traders (X1), Business Profiles (X2), Family Environment (X3), Characteristics of the Internal Business Environment (X4), Characteristics of the External Business Environment (X5) and Business Behavior (Y).

\section{Data Analysis Method}

This research analyzes personal characteristics, business profile, internal and external environment and business behavior. Personal characteristics and business profiles are analyzed using descriptive statistics. Analysis of the internal environment, the external environment of the business and entrepreneurial behavior are qualitative data that are quantified using a Likert scale. After calculating the score for each variable and sub-variable of the study, categorization consisted of: "very good" (score 5), "good" (score 4), "poor" (score 3), "not good" (score 2) and "very bad" (score 1). Analysis of the influence between variables used quantitative analysis namely the analysis of the Partial Least Square (PLS-Path Modeling) method. According to Jaya and Sumertajaya (2008), PLS is an alternative method of analysis with variance-based Structural Equation Modeling (SEM). Using the Smart PLS Version 2 program as tool that is specifically designed to estimate structural equations on the basis of variance.

The research hypothesis is: "Personal characteristic factors (X1), business profile (X2), family environment (X3), internal business environment (X4), external business environment (X5) have a significant effect on entrepreneurial behavior $(\mathrm{Y})$ of street food vendors in Pekanbaru.

\section{RESULT AND DISCUSSIONS}

\section{Street Vendors Characteristics}

The characteristics of street vendors are internal factors that are expected to have effect on entrepreneurial behavior. According to Johnson, 1990; Nishanta, 2008 (in Suharti \& Sirine, 2011), internal factors that come from entrepreuner's inside can be manifested as character traits, likewise socio-demographic factors like age, gender, family background, work experience and others which have effect on entrepreunerial behaviour of some person. External factors are factors that come from the external side of the entrepreneur which is surrounding environment.

Based on the research results, street vendors in Pekanbaru (Table 1), it is known that $95 \%$ of street vendors are in the productive age range, with an average age of 36.93 years and dominated $(63.36 \%)$ by men. The average education level of street vendors is 11.3 years (equivalent to high school). As many as 16.03 percent have an educational background equivalent to a bachelor's degree. According to (Welter \& Smallbone, 2011), well education level and knowledge can help an entrepreneur to adapt easily to their environment. With educational background, entrepreneurs can exploit opportunities, adjust easily to institutional structures shifting, and ability in contacting business networks to develop social networks to 
overcome institutional barriers, which are expected to also affect the income level of street vendors. In total $63.36 \%$ of street vendors had an income of less than IDR 500,000 / day with an average income of IDR 442,404 / day. This is higher than the Provincial Minimum Wage in Pekanbaru based on the Decree of the Governor of Riau Kpts.1198 / XI / 2019 (Sari Dewi, 2019), which is IDR 99,932 / day.

\section{TABLE 1. CHARACTERISTICS OF STREET VENDORS IN PEKANBARU}

\begin{tabular}{lrr}
\hline \multicolumn{1}{c}{ Street Vendor Characteristics } & Number & Percentage \\
\hline Seller Age (year): & 31 & \\
$18-27$ & 41 & 23.66 \\
$28-37$ & 31 & 31.29 \\
$38-47$ & 21 & 23.66 \\
$48-57$ & 7 & 16.03 \\
$58-67$ & & 5.34 \\
\hline Sex: & 83 & \\
Men & 48 & 63.36 \\
Women & & 36.64 \\
\hline Formal Education Level (year): & 20 & \\
Elementary School & 25 & 15.27 \\
Junior High School & 58 & 19.08 \\
Senior High School & 7 & 44.27 \\
Associate Degree & 21 & 5.35 \\
Bachelor & & 16.03 \\
\hline Entrepreneurial Experience (year): & 107 & \\
$1-9$ & 17 & 81.68 \\
$10-19$ & 6 & 12.98 \\
$20-29$ & 1 & 4.58 \\
$30-39$ & & 0.76 \\
\hline Familiy Dependent: & 94 & \\
$0-3$ & 37 & 71.76 \\
$4-6$ & 36 & 28.24 \\
\hline Income (IDR)/day & 34 & 27.5 \\
$<200.000$ & 61 & 25.9 \\
$200.00-500.00$ & & 46.6 \\
$>500.000$ & 37 \\
\hline
\end{tabular}

Based on Table 1, the entrepreneurial experience of street vendors is 5.27 years on average, with the shortest experience is 1 year and the longest is 39 years. Most of the street vendors as much as $81.68 \%$ had business experience between 1 to 9 years. Time of experience plays a role in influencing a person to become more skillful. Through experience, a person can learn many things because with less experience an entrepreneur will hardly to face, solve problems, and achieve opportunities. According to Buddhi Satyarini, (2016), the business experience possessed by entrepreneurs has the opportunity to give positive values to new businesses that will be opened and or the development of existing businesses.

In addition, the number of dependents in the family can be a source of motivation in doing business. The large number of family dependents encourages a person to be even more active in increasing household income. The average number of family dependents among the street vendors is 2 people. 


\section{Street Vendors Business Profile}

The informal sector, which is the street vendor, is characterized by a variety of businesses, ranging from small businesses to tents (angkringan food stalls). The types of food that sold by street vendors include: juice, crispy fried bananas, meatballs, bandrek, es doger, fried tofu, ankringan, pecel lele and others. Street vendors' business profiles are presented in Table 2.

TABEL 2. FOOD STREET VENDOR BUSINESS PROFILE IN PEKANBARU

\begin{tabular}{lcc}
\hline Profile & Number & Percentage \\
\hline Time of Business (year) & & \\
$1-\leq 3$ & 83 & 63.4 \\
$4-\leq 7$ & 28 & 21.3 \\
$>7$ & 20 & 15.3 \\
\hline Capital (Million Rupiah) & & \\
$0-\leq 1$ & 15 & 11.5 \\
$1-\leq 5$ & 48 & 36.6 \\
$5-\leq 10$ & 23 & 17.5 \\
$>10$ & 45 & 34.4 \\
\hline Capital Source & & \\
Own & 124 & 94.7 \\
Parents & 4 & 3 \\
Inheritance & 2 & 1.5 \\
Company & 1 & 0.8 \\
\hline Business License & & \\
Own & 62 & 47.3 \\
Not yet & 69 & 52.7 \\
\hline Number of Employee (person) & & \\
No employee & 52 & 39.7 \\
1 - 2 & 59 & 35.1 \\
3 - 4 & 19 & 14.4 \\
>4 & 1 & 0.8 \\
\hline Selling Schedule & & \\
Everyday & 125 & 95.4 \\
Monday - Saturday & 4 & 3.0 \\
Monday - Friday & 1 & 1.8 \\
Monday - Thursday & 1 & 1.8 \\
\hline
\end{tabular}

Based on Table 2, the amount of business capital for street vendors varies from IDR 200,000 to $50,000,000$ with an average starting capital of IDR $11,8226,717$. The number of capital depends on the type of business, capability and access to funding. Based on the sources of business capital for street vendors, it varies, including: own capital (94.7 percent) and other sources of capital, namely parents, inheritance and companies (5.3 percent). This is in line with the research of Rachmania et al., (2012), in family businesses in Indonesia, 85\% of all data obtained are types of businesses registered as self-owned. While $8 \%$ are business partnerships, $5 \%$ are cooperatives and $2 \%$ are other types of business.

Local governments including Pekanbaru City's government made a policy so that street vendors have business permits or Trade Registered Signs. Based on the results of the study (Table 2), a total of $47.3 \%$ of these street food street vendors have business licenses, 
while the rest more than half $(52.7 \%)$ do not have business license. This is similar with what was written by Saputra (2019), data from Bank Rakyat Indonesia (BRI) there are around 13,531 SMEs operating in Pekanbaru. Only about 3,000 (22.17\%) of SMEs have business licenses. Those who do not have this business license for various reasons, including some who do not know, some feel unnecessary and some say that it is complicated and difficult to deal with the bureaucracy. This regulation aims to ensure that street vendors can be disciplined and given guidance. The more the number of street vendor businesses that do not have business permits, it means that it is increasingly difficult to control and provide guidance.

Based on the number of employees, a number of 39.7 percent of street vendors businesses do not have employees or workers, which means using labor in the family. The number of workers/employees varies from one person to 4 employees and the most is having 8 people. Based on the SME category according to the World Bank (Bank Indonesia, 2015), this include micro business group, which has maximum workforce of 10 people. Based on the selling schedule, the results of the study (Table 2) showed that most (95.4\%) street vendors were selling every day. This reflects their tenacity to survive or to earn a living.

\section{Family Environment, Internal Environment, External Business and Enterpreneurial Behavior}

The business environment is the dynamic of the movement of the business that affects business performance, which consists of the internal (micro) environment and the economic environment which is the external or macro environment (Desi Martauli et al., 2016). Factors that are thought to affect entrepreneurial behavior are the family environment, the internal environment of the business and the external environment of the business. Munizu (2010) found that: i) individual manager/owner characteristics, business characteristics, external business environment, the impact of economic and social policies have a positive and significant direct effect on business strategy and business growth; ii) Small and micro enterprises will grow in a business environment with supportive regulations/policies and reliable information. Supporting policies enable businesses to be well managed and stable. Meanwhile, reliable and easily accessible information will have an impact on business success. The results of the study of these three factors (family environment, internal environment, external business) and entrepreneurial behavior are presented in Table 3. 


\section{TABLE 3. FAMILY ENVIRONMENT, INTERNAL ENVIRONMENT, BUSINESS EXTERNAL ENVIRONMENT AND ENTREPRENEURIAL BEHAVIOR OF STREET VENDORS IN PEKANBARU}

\begin{tabular}{|c|c|c|c|}
\hline Variable/Sub Variable & $\begin{array}{l}\text { Mean } \\
\text { Score }\end{array}$ & Achievement Score (\%) & Category \\
\hline Family Environment: & 3.82 & 76.33 & Good \\
\hline Parents education method & 4.55 & 90.91 & Good \\
\hline Family member relationship & 4.29 & 85.80 & Good \\
\hline Home atmosphere & 4.22 & 84.43 & Good \\
\hline Family economy condition & 4.27 & 85.49 & Good (supportive) \\
\hline Family supports & 4.38 & 87.63 & Good \\
\hline Family profession background & 3.33 & 66.26 & Less supportive \\
\hline Internal Environment & 4.24 & 84.27 & Good \\
\hline Financial Aspect & 4.08 & 81,68 & Good \\
\hline Production and operation technology & 4.26 & 84,12 & Good \\
\hline External Environment & 3.65 & 72.36 & Good \\
\hline General Government Policy & 2.92 & 58.93 & Less supportive \\
\hline Socio-economic environment & 4.40 & 88.09 & Good (supportive) \\
\hline Market competition & 4.20 & 83.96 & Supportive \\
\hline \multicolumn{4}{|l|}{ Entrepreneurial Behaviour: } \\
\hline Enthusiasm (Passion) & 4.69 & 93.89 & Good \\
\hline Independence & 4.25 & 85.65 & Good \\
\hline Sensitive to Market Opportunities & 4.46 & 89.16 & Good \\
\hline Creative and Innovative & 4.13 & 82.59 & Good \\
\hline Calculating the Risks & 4.10 & 81.83 & Good \\
\hline Service quality & 4.63 & 92.51 & Good \\
\hline
\end{tabular}

Note: Score range 1-5

\section{Family Environment}

External factors that influence entrepreneurial behavior include: family environment, community environment, college environment, technology environment, and opportunities. The family environment is the smallest group of community involving father, mother, children, and other family member. The family environment is expected to educate and support family members to have a business enthusiasm (Mochlasin \& Krisnawati, 2016). According to Rachmania et al., (2012), most Micro, Small and Medium Enterprises (UKM) begin from family businesses as a first step. There are many successful entrepreneurs that started from family business backgrounds. Then, the knowledge about the business types and the way family members support the business can become a thought for entrepreneurs to build their business. The results of the family environment research are presented in Table 3.

Based on Table 3, family environment in supporting entrepreneurial activities in general is in the "good" category. This is evident from the results of the study that the way parents educate, the relationship between family members, the atmosphere of the house, the economic condition of the family, the support of family members is in "good" category. A "Less Supportive" family environment is profession background of the parents or other family members (entrepreneurship or non-entrepreneurship). Street vendors who come from families whose main profession is entrepreneurship mostly foster motivation for doing entrepreneurship, apart from being a media for learning. 
According to Suharti \& Sirine (2011), family is the first environment that can foster a child's entrepreneurial mentality. The importance of the role of the family in encouraging children's interest in entrepreneurship was recognized by most of the respondents in a study conducted on students interested in entrepreneurship in Bandung. Likewise, according to Mochlasin \& Krisnawati, (2016), family is the closest social environment of an entrepreneur, which plays a very large role in shaping character, including the entrepreneurial character of a child.

\section{Internal Environment}

The internal environment of a business is the aspects of the business environment that are thought to have an effect on entrepreneurial behavior and business success. Abimbola and Agboola, 2011 (in Mochlasin \& Krisnawati, 2016) explain the relationship between entrepreurship and business environment. Abimbola and Agboola (2011) state that the environment, in this sense, covering factors such as infrastructure, culture, economics, social and political environment. Environmental forces have been observed to be capable of inhibiting or facilitating entrepreneurial activity in every society.

The results of the internal business environment are presented in Table 3. Based on Table 3, the internal business environment (financial and production technology aspects) is in the "good" category. Financial aspects that are in the "good" category are: street vendors using their own capital; perform a capital requirements analysis; conduct business profit analysis; is able to separate business finances from household finances and record business financial expenses and income.

Street vendor perceptions of production and operation technology are in the "good" category. The aspects included in the production technology of the business are: ease of obtaining raw materials; labor; ownership of machines that have guaranteed business continuity: mastering technical production. Maintaining product quality, employee has good technical skills and good morality.

\section{External Environment}

The external environment of business are factors or other aspects that come from outside the business that are thought to have an effect on entrepreneurial and entrepreneurial behavior. The aspects covering the external environment of the business analyzed include: general policies of the government; social and economic aspects and marketing environment.

Based on the research results in Table 3, the overall external environment of the business is considered "good". However, there is still an external environment that is still poorly assessed by street vendor which is the government general policy. The things that are perceived as unfavorable are: there is still a lack of government policies that support street vendors' access to finance; less intensive and continuous guidance and assistance for street vendors, lack of assistance in access to production technology, government regulations that do not take sides and support businesses; lack of monitoring and evaluation of empowerment programs that have been carried out. 


\section{Entrepreneurial Behaviour}

Street vendor entrepreneurial behavior is all the attitudes and activities of street vendors in running their business. Based on the research results (Table 3), overall entrepreneurial behavior is declared "good". The entrepreneurial behavior that street vendors think is good is evident from their independent behavior in doing business, among other things $94.7 \%$ of capital comes from their own capital. In addition, street vendors are sensitive to market opportunities, creative and innovative, risks management, quality service and managerial behavior that is able to manage a business well and a sustainable business (this is proven from their average time of business which is $36.6 \%$ has been established more than 4 years. In this entrepreneurial behavior, the most important thing is that street vendors realize that entrepreneurial behavior is not just to be studied but to be practiced for the sustainability of their business.

\section{Factors Affecting On Entrepreneurial Behavior}

The results of Outer loadings (measurement model) or convergent validity were employed to test the unidimensionality of each construct. According to Vinci et al (2010), the loading factor indicator value that is greater or equal to $0.5 \mathrm{can}$ be said to be valid. Thus, there are several invalid indicators (loading factor indicator below 0.5 ), this will affect the validity of the model. Therefore invalid indicators are eliminated so that a new model is formed (Figure 1).

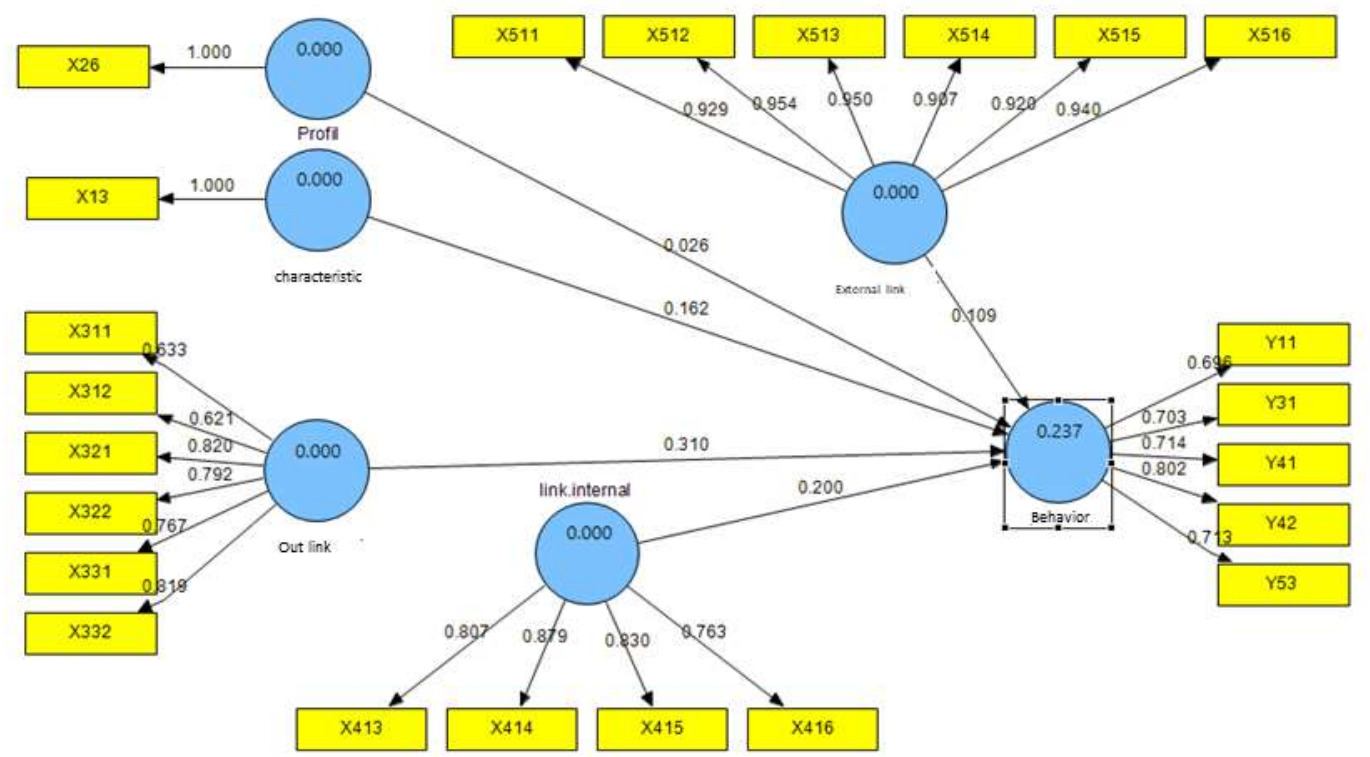

FIGURE 1. PLS OUTPUT RESEARCH MODEL WITH ALL INDICATORS LOADING FACTOR VALID : FACTORS THAT INFLUENCE ENTREPRENEURIAL BEHAVIOR OF STREET VENDOR

The results of Parameter Model Estimation Statistical Test (PLS output) Research are presented in Table 4. Based on the test results, it is known that significant indicators, namely the sub-variables and research indicators that have significant effect on entrepreneurial behavior. 
TABLE 4. STATISTICAL TEST RESULTS OF THE ESTIMATED MODEL RESEARCH PARAMETERS

\begin{tabular}{|c|c|c|c|c|}
\hline \multirow{2}{*}{ Variable } & \multirow{2}{*}{ Sub Variable } & \multicolumn{2}{|c|}{ Significant Indicator } & \multirow{2}{*}{$\begin{array}{l}\text { T Statistics } \\
(\mid \text { O/STERR } \mid)\end{array}$} \\
\hline & & Symbol & Description & \\
\hline $\begin{array}{l}\text { (XI) Personal } \\
\text { Characteristics }\end{array}$ & - & $\mathrm{X} 13$ & Educational Level & 11.0 \\
\hline (X2) Business Profile & - & $\times 26$ & Selling Schedule & - \\
\hline \multirow{6}{*}{$\begin{array}{l}\text { (X3) Family } \\
\text { Environment }\end{array}$} & \multirow{2}{*}{$\begin{array}{l}\text { X31 (Parent } \\
\text { Education Method }\end{array}$} & X311 & Set example of independence & 13.782112 \\
\hline & & X312 & Set example of persistence & 14.689882 \\
\hline & \multirow{2}{*}{$\begin{array}{l}\text { X32 (Family } \\
\text { Relationship) } \\
\end{array}$} & X321 & Seeing successful siblings & 34.124676 \\
\hline & & X322 & Family Support & 27.339282 \\
\hline & \multirow{2}{*}{$\begin{array}{l}\text { X33 (Home } \\
\text { Atmosphere) }\end{array}$} & X331 & Condusive home atmosphere & 21.906355 \\
\hline & & X332 & $\begin{array}{l}\text { Giving entrepreneurial example activity from } \\
\text { home }\end{array}$ & 35.258382 \\
\hline \multirow{4}{*}{$\begin{array}{l}\text { (X4) Internal } \\
\text { Environment }\end{array}$} & \multirow{4}{*}{$\begin{array}{l}\text { X41 (Financial } \\
\text { aspect) }\end{array}$} & X413 & Performing a Capital Requirement Analysis & 19.061726 \\
\hline & & X414 & Perform Business Profit Analysis & 35.595937 \\
\hline & & $X 415$ & Separation of business and household finances & 32.760081 \\
\hline & & $x 416$ & Already doing business bookkeeping & 19.841872 \\
\hline \multirow{6}{*}{$\begin{array}{l}\text { (X5) Eksternal } \\
\text { Environment }\end{array}$} & \multirow{6}{*}{$\begin{array}{l}\text { X51 (Public policy/ } \\
\text { Government Support } \\
\text { / } \\
\text { Related Institutions) }\end{array}$} & $\times 511$ & Support for access to finance & 123.504708 \\
\hline & & $x 512$ & Access training support & 182.522797 \\
\hline & & $\times 513$ & Technology access support & 80.509108 \\
\hline & & $\times 514$ & Conducive Government Regulation & 52.343088 \\
\hline & & $\times 515$ & Mentoring Activities & 81.468684 \\
\hline & & $x 516$ & Monitoring and Evaluation & 116.468669 \\
\hline \multirow{5}{*}{$\begin{array}{l}\text { (Y) } \\
\text { Entrepreneurial } \\
\text { Behaviour }\end{array}$} & Y1 (Enthusiasm) & Y11 & $\begin{array}{l}\text { Enthusiasm in seeking information, knowledge } \\
\text { and business skills }\end{array}$ & 26.739283 \\
\hline & $\begin{array}{l}\text { Y3 } \\
\text { (Sensitive to business } \\
\text { opportunities) }\end{array}$ & Y31 & Market opportunity seizing behavior & 22.936590 \\
\hline & \multirow{2}{*}{$\begin{array}{l}\text { Y4 } \\
\text { (Creative and } \\
\text { Innovative) }\end{array}$} & Y41 & Creating / looking for new ideas & 18.861052 \\
\hline & & Y42 & Turning new ideas into reality & 33.922651 \\
\hline & $\begin{array}{l}\text { Y5 (Calculating the } \\
\text { Risks) }\end{array}$ & Y53 & The courage to take risks & 25.031688 \\
\hline
\end{tabular}

Based on Figure 1 and Table 4, the factors that affect the model can be explained as follows:

\section{Personal Characteristics Factors Affecting Entrepreneurship Behavior}

Based on the research results (Table 4), it can be explained that the personal characteristics of street vendors that significantly influence entrepreneurial behavior are education. In theory, it is believed that providing a person with education and entrepreneurial experience from an early age can increase one's potential to become an entrepreneur. Several studies have shown results that support this statement (Kourilsky \& Walstad, 1998; Gerry et al., 2008 (in Suharti \& Sirine, 2011)). It turns out that educational factors are important in shaping entrepreneurial behavior and will ultimately affect business success. Several studies describe the relationship between education and entrepreneurship. Bhattacharjee, et al., (2008) argue that individuals who are more highly educated are desirous to leave from a bad labor market and therefore prefer independent entrepreneurs. This is also in line with the 
results of research by Syahardi et al., (2017) ) that the indicators of personal characteristics that most dominate the business performance of entrepreneurial women are education and family background.

\section{Family Environmental Factors that Have a Significant Influence on Entrepreneurial Behavior}

In addition to the personal characteristics of street vendors, family environment factor that have significant effect on entrepreneurial behavior are: the way parents educate their children, relationships between families and home atmosphere. The research by Fahed-Sreih et al., (2009) support the statement that the family plays a main role in business development in a transitional economy that has experienced severe socio-economic turbulence.

In this study, the interesting thing about the way parents educate children that affect entrepreneurial behavior is that parents educate children for independence and parents give examples to children so they don't give up easily when their business fails. In entrepreneurship, the factors of independence and never giving up are important things.

Other factors of the family environment that influence entrepreneurial behavior are: the relationship of family members and the atmosphere of the house. An influential relationship of family members is after seeing their siblings succeed in the business field. The success of family members turns out to be a motivation for street vendors to become entrepreneurs. Home atmosphere that supports entrepreneurship is a conducive home condition for entrepreneurship and provides examples of entrepreneurial activities starting from home. The findings of this study are also in line with the results of research by Syahardi et al., (2017), which states that the family environment affects entrepreneurial behavior and business performance.

3. Business Internal Environmental Factors that have significant influence on Entrepreneurial Behavior

The business environment factor that has a significant effect on entrepreneurial behavior is the financial factor. Meanwhile, production and operation technology for street vendors is not the main factor that determines entrepreneurial behavior. This means, with simple production technology, street vendors are able to start their business. Financial aspects that have significant effect are: the ability to analyze capital requirements, analyze business profits, ability to separate household and business finances and record financial expenses and income. The results of this study are in line with the business theories studied. The same thing was stated by Syahardi et al., (2017), that financial factors significantly influence business behavior and business performance.

4. Business External Environmental Factors that Have a Significant Influence on Entrepreneurial Behavior

The external environmental factors of business that have a significant effect on entrepreneurial behavior are the general policies of the government or related institutions. Social and economic aspects of the community do not really influence entrepreneurial behavior and the success of street vendors. This is understandable because street vendors snack food is sold at a price that is affordable to the general public and the street food sold 
also varies and is needed by the community. So that the social conditions and economic turmoil of the community do not affect street vendors. This is the specialty and attractiveness of the informal street vendors sector. This also differentiates it from medium and macro scale businesses and commodities outside of street food, which are sensitive to social and economic turmoil in society.

General government policy factors or related institutions that have a significant effect on entrepreneurial behavior and business success are:

a. Government policies support access to finance. Because street vendors have limited sources of capital. If the government helps street vendors access to finance it will greatly support entrepreneurial behavior and business success. Government support for this financing must be easily accessible to street vendors, among others: financing with no complicated bureaucracy and convoluted administration. Financing that is not burdensome to street vendors by repaying loans with interest.

b. Government support by providing training or financing to street vendors. The findings in the field indicate that street vendors with an average education level are inadequate, that is 11.5 years (equivalent to not completing high school). Street vendor empowerment can be improved by increasing knowledge, skills and mental attitudes. The training provided, for example, covers the following aspects: hygiene, product variety, business management, services and others.

c. Support from government or related institutions so that street vendors given more access to production technology. The quality and quantity of street food can be improved by street vendors if supported by production technology.

d. Government regulations that support street vendors businesses

e. Mentoring activities by the government for street vendors

f. Support from government or related institutions to monitor street vendors

The reliability of the research model is also shown in Table 5, namely the effect of exogenous latent variables and their indicators on exogenous latent variables. Based on the results of data analysis (Table 5), it turns out that the variables: personal characteristics, family environment, internal business environment and external business environment have significant effect (test level 5 percent) on the entrepreneurial behavior of street vendors. The variable that does not have significant effect on business behavior is the business profile. This means that entrepreneurial behavior can be improved through: Personal Characteristics of Traders, Family Environment, Internal Business Environment and External Business Environment.

Entrepreneurial behavior that is significantly influenced by personal characteristics, family environment, internal and external business is (1) enthusiasm (enthusiastic in seeking information, knowledge and business skills); (2) Creating market opportunities: (3) Creating / looking for new ideas; and (4) Courage to take risks. 
TABLE 5. STATISTICAL TEST RESULTS OF STRUCTURAL MODEL PARAMETER ESTIMATES

\begin{tabular}{|c|c|c|c|c|}
\hline \multicolumn{2}{|l|}{ Structural Equations } & $\begin{array}{c}\text { T Statistics } \\
\text { Effect }\end{array}$ & Description & R2 \\
\hline Endogenous Latent Variables & Exogenous Latent Variables & & & \\
\hline \multirow{5}{*}{ Entrepreneurial Behavior $(Y)$} & 1. Street Vendor Characteristics (XI) & 4.151654 & Significant & \multirow{5}{*}{0.237} \\
\hline & 2. Business Profile (X2) & 0.826418 & Not significant & \\
\hline & 3. Family environment (X3) & 7.221483 & Significant & \\
\hline & 4. Internal Business Environment (X4) & 4.133343 & Significant & \\
\hline & 5. Business External Environment (X5) & 2.606309 & Significant & \\
\hline
\end{tabular}

Enthusiastic behavior means that street vendors have enthusiasm and passion in running a business, even though there are many challenges, problems and risks that will be faced. Enthusiasm in the sense of not giving up easily or getting frustrated. Enthusiasm and passion are interesting things to describe in more detail. It seems the same but the essence is different. Enthusiasm is the energy to do a job because there is a willingness and desire to achieve it, namely the element of benefits and goals. Passion also means passionate. Passion is the energy needed to do a job because there are elements of love, preferences, and hobbies in it (loving). So, not solely because of the benefits and purposes. The source of energy needed in entrepreneurial activities or any activity is to have enthusiasm (there is hope) and passion to do it. This is supported by the results of research by Ayala \& Manzano, (2014). The results of his research indicate that the three dimensions of resilience (patience), resourcefulness (ingenuity), and optimism / having good expectations) help estimate entrepreneurial success.

An important key in creating an entrepreneurial spirit can be grown by several factors, namely:

a. A figure for someone to raise enthusiasm for seeing that person successful and rich so he wants to be like that person.

b. Like to find new challenges to create passion, loving entrepreneurship lifestyle.

c. Stuck or compulsion because you have to survive and live.

d. The desire to improve a better standard of living; do not want poor forever.

e. Experiencing failure in your work career and taking shortcuts for the spirit of being an entrepreneur.

f. Indeed, dream since childhood to become an entrepreneur.

The main requirement for street vendors to become strong in business is to be able to seize market opportunities by doing a good and precise market analysis. By doing a good and precise market analysis, the street vendors will be able to better understand the real market conditions so that the strategies taken will run well lead to business profits increasing. This point is very important because street vendors cannot serve all consumers or buyers in the market. There are too many buyers with diverse or varied needs and wants, so street vendors must identify which parts of the market it will serve as the target market. Thus, business success will affect how well and precisely market analysis is carried out.

Apart from being able to seize market opportunities, the entrepreneurial behavior of street vendors also determines the success of the business by creating / looking for new ideas (creative and innovative). Creativeness and innovation are affect and determine a person's 
success. If someone is trained to be creative since the childhood, in the future he is expected to be innovative to solve problems. As creativity of street vendors cannot happen instantly, but it takes a long process to develop until it reaches a certain point, as well as innovative point which needs to be.

The courage to take risks. The thing that distinguishes an entrepreneur from others is the readiness to take risks. In contrast to entrepreneurship, risk is used as a challenge to achieve success, not an obstacle that makes us fail. Entrepreuners are pushed to be always conscientious in taking risks. Self-confidence is have big role in taking risks. The higher the confidence someone posses, the bigger confidence is influencing decisions and results and as a result, the braver someone in facing risks that others doubt.

Based on Table 5, it is proven that all research hypotheses can be accepted. In conclusion, the characteristic factors, family environment, internal business environment and business external environment have a significant effect on entrepreneurial behavior. The latent variable of personal characteristics, family environment, and external environment of business influencing entrepreneurial behavior in the structural model has an $\mathrm{R}^{2}$ value of 0.276 which shows a moderate model.

\section{Model Reliability Test}

Based on the results of testing the goodness of the model (Table 6), for the measurement model seen from the value of composite reliability, AVE, and Cronbach Apla, all of them provide values that meet the criteria for the goodness of the model. So that the measurement model can be stated as good. This model proves that the characteristic factors of street vendors, family environment, internal business environment, and external business environment have a significant effect on entrepreneurial behavior. That is, the entrepreneurial behavior of street vendors can be increased by increasing or improving with non-formal education, support and education from the family, improving the internal business environment (especially capital / finance) and support from the government.

TABLE 6. RESEARCH MODEL GOODNESS TEST RESULTS

\begin{tabular}{lllll}
\hline Variable & $\begin{array}{l}\text { Composite } \\
\text { Reliability }\end{array}$ & AVE & $\begin{array}{l}\text { Cronbach } \\
\text { Alpha }\end{array}$ & Information \\
\hline Street vendor characteristics $\left(X_{1}\right)$ & 1.000000 & 1.000000 & 1.000000 & Good (fit) \\
\hline Business Profile & 1.000000 & 1.000000 & 1.000000 & Good (fit) \\
\hline Family environment $\left(X_{2}\right)$ & 0.881898 & 0.557563 & 0.839513 & Good (fit) \\
\hline Internal Business Environment $\left(X_{3}\right)$ & 0.891719 & 0.673650 & 0.842025 & Good (fit) \\
\hline External Business Environment $\left(X_{4}\right)$ & 0.976007 & 0.871495 & 0.971054 & Good (fit) \\
\hline Entrepreneurial Behavior $\left(X_{5}\right)$ & 0.848125 & 0.528317 & 0.776640 & Good (fit) \\
\hline
\end{tabular}

\section{CONCLUSIONS}

The conclusion of the research shows that the personal characteristics of street vendors average are 36.93 years old, the level of education is equivalent to high school, business experience 5.27 years and the average net income per day is IDR 442,404,-. Street vendors operating capital of IDR 200,000 to 50 million with an average starting capital of IDR 
$11,8226,717$ depending on the type of business, ability and access to capital. The sources of street vendors business capital varied, namely: own capital (94.7 percent) and other sources of capital, namely parents, inheritance and companies (5.3 percent). 52.7 percent of street vendors businesses do not have business permits.

The family environment and the internal environment of the business are considered "good" and support street vendors. The external environment of business, especially government support or policies (support for capital, technology and empowerment) is still considered "not good" by street vendors. Entrepreneurial behavior which includes: enthusiasm, independence, sensitivity to market opportunities, creative and innovative, calculating risk, service quality and managerial behavior as a whole is perceived as "good" by street vendors.

The factors that significantly influence entrepreneurial behavior are: personal characteristics factors (formal education); family environmental factors (independence and resilience education from parents, examples of success from family members and a conducive home atmosphere that supports entrepreneurship); business internal environmental factors (financial analysis and separation of business and household expenditures) and business external environmental factors are government policies that help street vendors to access finance, training, production technology, government regulations that support business, mentoring and monitoring / evaluation of mentoring programs). Significant indicators shape entrepreneurial behavior, namely; (1) Enthusiasm (enthusiastically seeking information on business knowledge and skills); (2) Behavior seizing market opportunities: (3) Creating / looking for new ideas; and (4) Courage to take risks.

Based on the research findings, the low level of formal education of street vendors in Pekanbaru City and the education factor has a crucial effect on entrepreneurial behavior, it is suggested to improve the entrepreneurial behavior of street vendors in order to obtain business success. This is by increasing the capacity (knowledge, skills and mental attitudes) of street vendors through empowerment programs or capacity building for street vendors and facilitating street vendors to access various resources (capital, technology, policies that support the progress of street vendors) by the government, non-profit organizations, universities, institution or other related institutions.

\section{ACKNOWLEDGEMENTS}

Thanks are conveyed to the Riau Islamic University Research and Community Service Institute for funding this research. The same remarks are also conveyed to all parties who have helped the completion of this research.

\section{REFERENCES}

Ayala, J. C., \& Manzano, G. (2014). The resilience of the entrepreneur. Influence on the success of the business. A longitudinal analysis. Journal of Economic Psychology. https://doi.org/10.1016/j.joep.2014.02.004 
Azwar, B. (2013). Analisis Faktor-faktor yang Mempengaruhi Niat Kewirausahaan (Entrepreneurial Intention). Studi Terhadap Mahasiswa Universitas Islam Negeri SUSKA Riau. Jurnal Menara.

Badan Pusat Statistik Provinsi Riau (2018). Potensi Usaha Mikro Kecil Provinsi Riau. Katalog/Catalog: 9102067.14. SensusEkonomi.

Bank Indonesia-LIPPI. (2020). Profil Bisnis Usaha Mikro, Kecil Dan Menengah (UMKM). Kerjasama LPPI dengan Bank Indonesia. Jakarta

Bhattacharjee, a., Bonnet, J., Le Pape, N., \& Renault, R. (2008). Entrepreneurial motives and performance: why might better educated entrepreneurs be less successful? CergyPontoise: Working Paper Du THEMA, Université de Cergy-Pontoise.

Buddhi Satyarini, T. (2016). Karakter Wirausaha pada Industri Mikro Pangan Olahan di D.I.Y dan Faktor-Faktor yang Mempengaruhi. AGRARIS: Journal of Agribusiness and Rural Development Research, 2(1), 28-35. https://doi.org/10.18196/agr.2123

Cho, Y., \& Honorati, M. (2014). Entrepreneurship programs in developing countries. A meta regression analysis. Labour Economics, 28, 110-130. https://doi.org/10.1016/j.labeco.2014.03.011

Dirlanudin. 2010. Perilaku Wirausaha dan Keberdayaan Pengusaha Kecil Industri Agro: Kasus di Kabupaten Serang Provinsi Banten [Disertasi]. Bogor: Institut Pertanian Bogor.

https://repository.ipb.ac.id/jspui/bitstream/123456789/55034/3/2010dir.pdf

Desi Martauli, E., M. Baga, L., \& Fariyanti, A. (2016). Faktor-Faktor Yang Berpengaruh Terhadap Kinerja Usaha Wanita Wirausaha Kerupuk Udang di Provinsi Jambi. AGRARIS: Journal of Agribusiness and Rural Development Research, 2(2), 118-127. https://doi.org/10.18196/agr.2232

Fahed-Sreih, J., Pistrui, D., Huang, W., \& Welsch, H. (2009). Family contributions to entrepreneurial development in Lebanon. International Journal of Organizational Analysis. https://doi.org/10.1108/19348830910974941

Fajrin, A. R. M., \& Rahmawati, D. (2016). Faktor-Faktor yang Berpengaruh dalam Penataan Pedagang Kaki Lima (PKL) pada Koridor Jalan Pasar Besar Kota Malang. Jurnal Teknik ITS, 5(1). https://doi.org/10.12962/j23373539.v5i1.11414

Hadya Jayani, D. (2020 April 8). Pemerintah Beri Stimulus, Berapa Jumlah UMKM di Indonesia? https://databoks.katadata.co.id/

Jaya, I. G. N. M., \& Sumertajaya, I. M. (2008). Pemodelan Persamaan Structural dengan Partial Least Square. Semnas Matematika Dan Pendidikan Matematika 2008.

Kemepade Moruku, R. (2013). Does entrepreneurial orientation predict entrepreneurial behaviour? International Journal of Entrepreneurship.

Kementerian Koperasi dan UKM RI. 2019. Perkembangan Data Usaha Mikro, Kecil, Menengah (UMKM) Dan Usaha Besar (UB) Tahun 2017 - 202018. http://www.depkop.go.id/data-umkm 
Koyana, S., \& Mason, R. B. (2017). Rural entrepreneurship and transformation: the role of learnerships. International Journal of Entrepreneurial Behaviour and Research. https://doi.org/10.1108/IJEBR-07-2016-0207

Mochlasin, M., \& Krisnawati, W. (2016). Faktor-Faktor yang Mempengaruhi Perilaku Kewirausahaan Enterpreneur Muslim Salatiga. Muqtasid: Jurnal Ekonomi Dan Perbankan Syariah. https://doi.org/10.18326/muqtasid.v7i2.73-94

Nursiah, T., Kusnadi, N., \& Burhanuddin, B. (2017). Perilaku Kewirausahaan pada Usaha Mikro Kecil (UMK) Tempe di Bogor Jawa Barat. Jurnal Agribisnis Indonesia, 3(2), 145. https://doi.org/10.29244/jai.2015.3.2.145-158

Purnawati, L. (2016). Evaluasi Penataan dan Pemberdayaan Pedagang Kaki Lima Dari Taman Aloon-Aloon Kabupaten Tulungagung. Jurnal Evaluasi Penataan Dan Pemberdayaan Pedagang Kaki Lima.

Rachmania, I. N., Rakhmaniar, M., \& Setyaningsih, S. (2012). Influencing Factors of Entrepreneurial Development in Indonesia. Procedia Economics and Finance, 4, 234-243. https://doi.org/10.1016/s2212-5671(12)00338-3

Saputra, S. (2020, Juli 05). Ribuan UMKM Belum Berizin. https://riaupos.jawapos. com/pekanbaru/24/01/2019/193595/ribuan-umkm-belum-berizin.html

Sari Dewi, R., (2019 November 23). Ini Daftar Lengkap UMK 2020, di Riau Dumai Tertinggi. https://www.goriau.com/berita/baca/ini-daftar-lengkap-umk-2020-di-riau-dumaitertinggi.html

Schmidt, S., Bohnenberger, M. C., Panizzon, M., Marcon, S. R. A., Toivonen, E., \& Lampinen, M. (2018). Students entrepreneurial behaviour: An eight-construct scale validation. International Journal of Entrepreneurship.

Suharti, L., \& Sirine, H. (2011). Pengaruh Faktor Sosial Demografi dan Faktor Kontekstual Terhadap Niat Kewirausahaan Mahasiswa. Prosiding Seminar Nasional Kewirausahaan Dan Invasi Bisnis (SNKIB) I, Universitas Tarumanagara Jakarta, 194222. http://repository.uksw.edu/handle/123456789/197

Sulistyo Rini, H. (2013). Dilema Keberadaan Sektor Informal. Komunitas: International Journal of Indonesian Society and Culture. https://doi.org/10.15294/ komunitas. $\mathrm{v} 4 \mathrm{i} 2.2415$

Syahardi, A., Baga, L. M., \& Winandi, R. (2017). Faktor-Faktor Yang Memengaruhi Kinerja Usaha Wanita Wirausaha Pada Industri Makanan Ringan Di Provinsi Sumatera Barat. Forum Agribisnis, 7(2), 161-172. https://doi.org/10.29244/fagb.7.2.161-172

Vinci, V.E., Chin, W.W., Henseler, J.and Wang, H. (2010). Handbook of Partial Least Square. Concepts, Methods and Aplication. Springer-Verlag Berlin Heidelberg.

http://www.springer.com/series/7286

Welter, F., \& Smallbone, D. (2011). Institutional Perspectives on Entrepreneurial Behavior in Challenging Environments. Journal of Small Business Management. https://doi.org/10.1111/j.1540-627X.2010.00317.x 